\title{
4 Translation, Transcription, and What Else? Some Basic Characteristics of Chinese Buddhist Translation as a Cultural Contact between India and China, with Special Reference to Sanskrit ārya and Chinese sheng
}

\subsection{Introduction}

Chinese Buddhist translations were made for over nine hundred years, from the Later Han to the Northern Song dynasties. Translation activity was interrupted in the Southern Song, resumed in the Yuan, and finally continued until the Qing dynasty, though the scale became considerably smaller. ${ }^{1}$ In this article, I will attempt to explore some basic characteristics of Chinese Buddhist translation (hereafter abbreviated as CBT) from a macroscopic point of view. CBT was translation from an Indic language such as Sanskrit to classical Chinese, but it is too simplistic to assume that it was a smooth one-way transmission from India to China; a variety of cultural gaps between India and China should be taken into consideration to grasp the essential characteristics of CBT.

Buddhism had a serious impact on Chinese culture, contributing important new ideas such as the notion of samsāra (endless transmigrations and reincarnations). It also brought Indian material culture to China. ${ }^{2}$ On the other hand, from a linguistic perspective, unlike other languages such as Tibetan, Chinese was not

1 Strictly speaking, the translation activity for those nine hundred years included the occasional hiatus. There were two remarkable hiatuses in particular: one began in the second half of the fifth century, lasting at least for some decades with a few minor exceptions; and the other for one hundred and sixty or seventy years after the Indian monk Prajñā's translation of the Dasheng bensheng xindi guanjing 大乘本生心地觀經 in 810-811. Funayama (2013, 36-38, 45-46, 244).

2 For a major study of this topic, see Kieschnick (2003).

Note: I want to thank Dr. Ryan Overbey for his kind help to refine my English. This paper is based on material already examined in Funayama (2013, in Japanese). I have added some significant new information about primary sources.

Ә Open Access. (C) 2019 Toru Funayama, published by De Gruyter. (c) BY-NC-ND This work is licensed under a Creative Commons Attribution-NonCommercial-NoDerivatives 4.0 International License.

https://doi.org/10.1515/9783110413083-004 
subject to any positive change when it adopted Buddhism. Linguistically, China remained China even after this massive import of Indian culture. Nevertheless, there are some non-negligible aspects of Indian Buddhist language that contributed - however partially - to some noteworthy changes in the Chinese language. Provisionally, I want to pay attention to the following four points:

The first is the creation of new Chinese characters for transcription. ${ }^{3}$ A typical example of transcription is anouduoluo sanmiao sanputi阿耨多羅三藐 三菩提 for Skt. anuttarā samyak-sambodhi (“the unsurpassed, correct and perfect awakening”). It is literally translated as wushang zhengdengjue無上正等覺. Incidentally, “translation" is sometimes called yiyi 義譯 (“the rendition by meaning") in traditional commentaries and compendia. In the process of Chinese Buddhist translations, Chinese characters such as mo 魔, fan 梵, ta 塔, seng 僧, bo 鉢, sa 薩, qie 伽, and jiasha 袈乷 were newly created for transcription; they had not existed before the Chinese adoption of Buddhism (Funayama 2013, 181-187). ${ }^{4}$ On the other hand, some Chinese characters were used especially for transcription. Examples of such words are fo 佛, tuo 陀, ni 尼, jia 迦, pi 毘, pu 菩, ji 偈, na 那, and luo 羅. These had existed before the Chinese adoption of Buddhism and were not newly created characters, but they were used only for transcription with no meaning of their own (Funayama 2013, 187).

Second, CBT was by and large word-for-word translation, not sentence-forsentence translation. However, CBT partially inspired some new usages of Chinese particles (zhuzi 助字). For example, the use of gu 故 (“because”) put at the end of a sentence was not at all popular in the period prior to Buddhism, whereas it was frequently used in CBT. This is because a reason-phrase is put after the proposition in Sanskrit, as follows:

A sound is impermanent, because of being a product.

Skt. anityah śabdah, krtakatvāt.

Ch. 聲是無常, 所作性故. ${ }^{5}$

3 By “transcription," I mean what is traditionally called yinyi 音譯 (lit. "translation by phonemes"); other options for the same sense are "phonetic transcription" and "transliteration." In contrast to yinyi, normal translation is traditionally called yiyi 義譯 (lit. "translation by meanings").

4 Characters such as cha 刹 and chan 懺 and bai 唄 may also have been made for Chinese Buddhist translations as assumed by some previous studies, but verification will require further careful investigation, including specification of their earliest usages.

5 The Sanskrit and Chinese passages are quoted from the Nyāyapraveśa (Śańkarasvāmin) and its Chinese translation Yinming ru zhengli lun 因明入正理論 by Xuanzang (T32, 12a). 
This type of $g u$ also gave rise to further peculiar phrases such as $y i \ldots g u$ 以...故 and wei ...gu 為... 故 that are often used in CBT to express reason or purpose. ${ }^{6}$

Third, quite a few texts of CBT feature repetition of four-character phrasing, which did exist even before the advent of Buddhism. However, as Yoshikawa Kōjirō ([1958] 1968) observed, the rather tedious phrasing of four, four, four, four was not as popular in indigenous, non-Buddhist texts.

Yet another impact of Buddhist translation on Chinese language was the production of new words to express Buddhist technical terms such as yuanqi 縁 起 (pratityasamutpāda), shijie 世界 (lokadhātu), fannao 煩惱 (kleśa), and the above-mentioned lunhui 輪迴 (samsāra), just to mention a few.

It is not necessary to enumerate all the varieties of Buddhist influence on Chinese language. ${ }^{7}$ Here I just want to indicate a fact: once the above-stated characteristic elements of CBT were acknowledged by Chinese monks and literati, some of them started to adopt this style in their own writings. Just to mention one, a mechanical repetition of four-character phrasing is discernible in numerous parts of Huisi's 慧思 (515-77) text entitled the Gate of the Samādhi Wherein All Entities are Without Dispute (Zhu fa wuzheng sanmei famen諸法無諍 三昧法門 T no. 1923). ${ }^{8}$

Now, let's examine the significance of transcription and its relation to translation. This gets at the basic problem of identity and/or difference between the meaning of the original Indic term and the Chinese translation, especially when an Indic term does not have a precise Chinese equivalent bearing exactly the same meaning. In my view, this reveals one of essential characteristics of CBT.

I would like to highlight two contexts in which precise translation is remarkably difficult. The first is the case of highly developed technology such as the modern vocabulary of computers. In the case of modern Japanese, for instance, we use these words in the form of transcription in katakana and do not give any real Japanese translation of their meanings. In the case of CBT, this manifests as transcription using Chinese characters.

The other difficult case of untranslatability from one language to another is related to religious concepts. In this case too, one could use transcription if translation is not possible. But such transcription can be problematic if readers cannot understand the meaning behind the transcription. On the other hand, one could also render the original term using an indigenous term in the target

6 The phrase $y i \ldots g u$ 以...故 is used to show the reason with instrumental case or ablative case and wei ...gu 為...故 is used as a translation of either "because of ...” with ablative (occasionally instrumental) case or "for the purpose of ..." with dative case.

7 For further points and examples, see Funayama (2013, 177-208).

8 E.g., a passage (T46, 633a) indicated in Funayama $(2013,198)$. 
language. Almost all cultures have their own religions, and religious words are so fundamental and deeply bound up with culture that it is extremely difficult to precisely translate a foreign religious term to one's own language without using a term of one's own religion. ${ }^{9}$ Quite a few terms of religion in a source language cannot be translated without using indigenous terms of religion in the target language. For example, it is widely known that Matteo Ricci (1552-1610) translated Deus as tianzhu 天主 (“Heavenly Lord”) in Chinese, explaining it as shangdi 上帝 ("Supreme Monarch"). In this case those who read the explanation of Deus by "Supreme Monarch" would be inevitably led to an association of god with a nuance of secular sovereign.

\subsection{On "Translation by Matching Cultural Categories"}

In this way the activity of producing CBT was not only important for individual translations themselves, but also reveals how Buddhists struggled with the problem of untranslatability which underlay the gulf between Indian and Chinese cultures and languages. When an Indic term was difficult to translate literally, Chinese Buddhist translators had recourse to giving either a transcription of the Indic term or a kind of paraphrase by using a Confucian or Daoist term that, despite serious difference in the literal sense, could partially work in a similar context. If the translation fully matches the original meaning, no problem arises. However, if a translation has any deviation from the original meaning in Sanskrit or Pāli, it entails the possibility of misunderstanding; an inadequate translation could misrepresent or distort the original sense. A transcription, on the other hand, was potentially incomprehensible, because it can convey no meaning through the sequence of Chinese characters, and readers with no knowledge of the source language could not understand the original meaning.

For example, Skt. nirvāṇa (or Pāli nibbāna) was transcribed as niepan 涅槃. Nihuan 泥洹 and niyue 泥曰 were also used in earlier times. Nihuan is used as early as the later Han dynasty, as found in Lokakșema's [Zhi Loujiachen支婁迦識] translation Daoxing bore jing 道行般若經 (Karashima 2010, 336-337). In this case, the Chinese characters of the transcription convey no meaning. Hence if

\footnotetext{
9 As discussed in Funayama (2013, 209-210), Suzuki nicely describes a really intriguing account of serious problems Francisco Xavier (1506-1552) had in his propagation of belief in God in Japanese, especially his use of “dainichi 大日” (as a translation of God by matching cultural categories) and "deusu" (as a transcription of Deus).
} 
a transcribed term such as niepan was totally new to Medieval Chinese readers, and had not yet passed into general usage, then readers simply could not understand the transcription. Understanding the meaning of niepan was possible only when readers knew Sanskrit or when they had become familiar with actual usages of niepan in Chinese.

Actually, this term was not always transcribed in the earliest stage of CBT. As is well known, the Daoist term wuwei 無為 ("non-action") was employed as a translation of nirvāna in the corpus of the earliest translator, An Shigao 安世高 in the Later Han. The Da Anban shouyi jing 大安般守意經 (Taisho no. 602) has an interesting passage which says:

An is purity. Ban is clarity. Shou is nothing. Yi is called action. [Putting all together, Anbanshouyi means the condition of] pure and clean non-action. (安為清, 般為淨, 守為 無, 意名為, 是清淨無為也. T15, 164a)

This appears in translation, but it cannot be a literal translation from an Indic language. It looks like an exegetical element interpolated in translation, though it is not at all clear whether this "interpolation" was made by An Shigao or someone else at a later period. Anyway this is an example of the use of a Daoist term wuwei in early CBT. It was only later that translations such as miedu 滅度 (lit. "passage into extinction") appeared in CBT. ${ }^{10}$

Furthermore, Stefano Zacchetti (2002, 87) successfully identified wuwei which is used in another An Shigao translation, entitled Yin chi ru jing 陰持入經 (Taisho no. 603), with nibbāna in the Pețakopadesa in Pāli. However, wuwei as a translation of nirvāna did not last long because it was too Daoistic and misleading as a Buddhist translation. *Lokakșema preferred the transcription nihuan in his translation of the Perfect Wisdom Sutra entitled the Daoxing bore jing 道行般 若經 (Karashima 2010, 336).

It is also widely known that the Daoxing bore jing and some other earlier translations of the Perfect Wisdom Sutra have the translation benwu 本無 for tathatā ("suchness"; e.g., Karashima 2010, 28-31), a term which later translations would render with zhenru 真如. ${ }^{11}$

I would like to tentatively call this type "translation by matching cultural categories."12 By this special term, I mean the translation of an Indic term based on

10 Xuanzang 玄牀, the most important translator, sometimes preferred yuanji 圓寂 (“complete tranquility") for parinirvāṇa.

11 For a study of zhenru as a translation, see Kaginushi (1968).

12 "Translation by matching cultural categories" is an English equivalent for what I tentatively call “bunka taiō gata yakugo" 文化対応型訳語 in Japanese. For this notion, see Funayama 
a traditional Chinese concept that is similar to the original Indic term, yet not literally identical. It is not a literal translation of the original "meaning," but the indication of an equivalent concept that more or less works similarly in the Chinese cultural context. Thus wuwei is not a literal translation of nirvāna, but can convey the basic religious significance to some extent. Needless to say, such expedient translation may lead to serious misunderstanding of the term, especially for those who do not have any knowledge of the original Indic language.

In what follows, I will briefly introduce other five cases of "translation by matching cultural categories."

1. Dao 道 (“way”) for Skt. bodhi (“awakening, enlightenment”). Expressions such as daoshu 道樹 for Skt. bodhi-vṛkșa or bodhi-druma ("bodhi-tree”) under which the Sākyamuni became enlightened and chengdao 成道 for Skt. sambodhi/abhisambodhi ("perfect/supreme awakening”) are examples of "translation by matching categories" because "dao" evidently comes from the Daoist notion, and does not mean a "path" (e.g., Skt. mārga) in these cases.

(2013, 214-215) (I owe the English translation of this Japanese to Dr. Michael Radich who kindly thought about some optional expressions for this Japanese word; however any problems with this notion either in English or in Japanese are my own responsibility). This type of translation is in a sense similar to so-called geyi 格義 (matching concepts), but it should be distinguished from geyi in that geyi has no direct relation to the work of translation. According to Mair (2010), the original notion of geyi had nothing to do with the process of translation. Geyi was a technique to interpret Chinese Buddhist texts using non-Buddhist categories from Daoism or Confucianism. It is a method to elucidate a term, not a method of translation. Nor should it be used in the periodization of Chinese Buddhism; as Kobayashi (1997) and Mair indicate, the use of the term “kakugi bukkyō” 格義佛教 (Matching Concepts Buddhism) to signify a period of Chinese Buddhism was a modern Japanese creation, and such a period never existed in history. Rather, those who actually applied geyi for the interpretation of Buddhist texts were quite limited in number. In the Biographies of Eminent Monks (Gaoseng zhuan 高僧傳), the actual description of geyi is found only in the biographies of Zhu Faya 笈法雅 (a contemporary of Dao'an 道安 [312-85]), Sengxian 僧先, and Huiyuan of Mt. Lu 盧山慧遠 (334-416). While we should not confuse the notion of geyi with the process of CBT, I still believe that we can pay special attention to this unique and heuristically convenient notion - which embodies one of essential characteristics of Chinese Buddhism - by intentionally extending the concept of geyi to a broader context. In this sense, I would like to propose the distinction between a real geyistyle of interpretation, which is the original sense of the term, and translation by matching cultural categories. In a sense we may be able to say that what I call "translation by matching cultural concepts" is a "geyi-like" (or "quasi-geyi") translation method, but not geyi itself in the strict sense. For example, wuwei as a translation of nirvāna is a translation by matching cultural categories, but it should be distinguished from a geyi-style of interpretation. 
2. Jing 經 ("warp thread") for Skt. sūtra ("thread, yarn”). The original meanings of jing and sūtra are thus similar but not identical. ${ }^{13}$ Especially in China, the word jing had a special meaning, hence the word jingdian 經典 to refer to Confucian classics. It is possible that Chinese Buddhist translators intentionally chose the word jing for sūtra in order authorize Buddha's words as comparable to the words of ancient sages in Confucianism. Incidentally, later scholar-monks such as Jingying Huiyuan 淨影慧遠 (523-92) and Zhiyi 智顗 (538-97) elucidate the meaning of jing by paraphrasing it into chang 常, implying that sütra contains eternal truth. ${ }^{14}$ This type of Chinese interpretation is divorced from the meaning of sūtra in Sanskrit.

3. Long 龍 (“Chinese dragon”) for Skt. nāga ("a snake or a serpent-like demon"). ${ }^{15}$ Interestingly nāga is nearly always translated as long, though the Chinese dragon is obviously not entirely the same as the nāga in India. ${ }^{16}$ To the best of my knowledge, no example of she 蛇 for nāga has been attested. Most probably this is because the mythical and overwhelming power of nāga can best be expressed by long in Chinese, whereas she cannot convey such a nuance.

4. Ganlu 甘露 (“sweet dew”) for Skt. amrta (lit. “non-death," “immortal”). One of the earliest examples is found in *Lokakșema's translation Daoxing bore jing (Karashima 2010, 179). It was occasionally translated as busi 不死, but ganlu was much more popular throughout the history of CBT. Linguistically speaking, ganlu is not a translation of amrta, but merely an equivalent concept found in Chinese culture. ${ }^{17}$ As already indicated in dictionaries and other reference works, the word ganlu had been used in Chinese indigenous texts such as the Laozi Chapter 32, signifying sweet dews that pervade the realm as a result of the virtue of a benevolent king. ${ }^{18}$ In the case of Tibetan, on the

13 For the etymology of Skt. sūtra, see Mayrhofer (1963, 492) and Mayeda (1964, 227-266).

14 Huiyuan's 慧遠 Commetary on the Nirvāna-sūtra (Daban niepan jing yi ji 大般涅槃經義記 T37, 614b). Zhiyi's智顗Commentary on the Lotus Sutra (Miaofa Lianhua jing xuan ji 妙法蓮華經 玄記 T33, 753a).

15 For Skt. nāga, the word xiang 象 “elephant” is also occasionally used, because Skt. nāga implied the meaning of elephant.

16 A Chinese dragon has claws on four legs, can fly in the air, and is large enough for human or a transcendent to ride on it and fly, while a nāga does not have claws, does not fly, and is rather small in size.

17 According to Wogihara ([1979] 1986, 994b), one of the original Sanskrit words of ganlu can be madhu-vindu (lit. "sweet drop[s]"; vindu for bindu), found in the Lalitavistara. But in my view, this usage occurs only rarely.

18 Laozi Chapter 32: 道常無名。樸雖小, 天下莫能臣也。侯王若能守之, 萬物將自賓。天地相 合, 以降甘露, 民莫之令而自均。“The Dao, considered as unchanging, has no name. Though 
other hand, the standard translation is bdud-rtsi which literally means the “drink of gods"; generally speaking, the idea of "sweet” (Ch. gan 甘) is not found in Tibetan translation.

5. Zhenren 真人 (“a true person”) for Skt. arhat. The standard transcription of arhat is aluohan 阿羅漢 or luohan. Although this transcription is used in the earliest period, earlier translators also made use of a translation zhenren for arhat. As a synonym of xianren 仙人 “transcendent” or “immortal," zhenren is a well-known term to signify an ideal practitioner. I will discuss the significance of the notion of zhenren again in the next section.

The above-stated examples reveal that "translation by matching cultural categories" deeply influenced CBT. ${ }^{19}$ In other words, much of the basic vocabulary of Chinese Buddhism cannot be understood without attending closely to this type of translation. In these cases a term often takes on a doubled meaning, and accordingly a reader's understanding also swings between purely Indic and purely Chinese meanings. If a reader is familiar with the original Sanskrit word, he understands the Chinese translation such as daoshu merely as a translation of bodhi-tree, but if he has no knowledge of Sanskrit, he will understand the meaning more in the Daoist sense.

\subsection{Skt. ärya and Ch. sheng}

Next, I would like to consider yet another fundamental term of religion: the notion of saintliness. The terms I will take up now are Skt. ārya, Tib. 'phags $p a$, and $\mathrm{Ch}$. sheng. Let me start my observations from the original meaning of Ch. sheng.

in its primordial simplicity it may be small, the whole world dares not deal with (one embodying) it as a minister. If a feudal prince or the king could guard and hold it, all would spontaneously submit themselves to him. Heaven and Earth (under its guidance) unite together and send down the sweet dew, which, without the directions of men, reaches equally everywhere as of its own accord" (tr. by James Legge in Chinese Text Project; http://ctext.org/).

19 There are more examples of "translation by matching cultural categories"; e.g., Skt. deva "god, heaven" (often used in plural in Sanskrit) is usually translated by tian 天 "heaven" (usually used in singular in Chinese). 
The original meaning of sheng was rather simple: a wise or intelligent person who could have some connection with Heaven. ${ }^{20}$ It was not used to refer to a supreme person such as a "sage."21

However, the notion changed from around the middle of the fifth to the third centuries BCE, when Confucianism became predominant in Chinese thought. The word began to be used in a more limited way to signify a person who has perfectly embodied human morals, merits or virtues. Such an idea can be found in the Analects (Lunyu 論語), one of the most fundamental and influential scriptures of Confucianism.

Sage as the monarch of the world - Moreover in the same period, sheng was also applied to a perfect ruler or sovereign of the world who embodied the abovementioned human virtues. And this view led to the general image of the shengren 聖人 ("sage”) in later times. Normally Confucian tradition admits only eight persons as sages through the age of Kongzi (active ca. 551-ca. 479 BCE): 1 Yao di 堯 帝 - 2 Shun di 舜帝 - 3 Yu wang 禹王 - 4 Tang wang 湯王 - 5 Wen wang 文王 - 6 $\mathrm{Wu}$ wang 武王 - 7周公旦 Zhougong Dan (Duke Dan of Zhou) - 8 Confucius (Kongzi 孔子).

Building on this assumption, though not directly related to Confucianism, all emperors were also called shengren or shengdi 聖帝 (“sage-emperor”) because they were monarchs of Chinese Empire. One of the earliest examples of such usage is found in the Book of the Later Han (Hou hanshu 後漢書), in particular in

20 More concretely, the meaning of sheng in an earlier period, if not the earliest, is found in the Shuowen 説文, a well-known etymological dictionary composed by Xushen 許慎 in 100 CE. It defines the word sheng as a synonym of tong 通 “to penetrate," “to pass through." And according to previous studies, especially an article by Rodney Taylor (1988, 219), the Shuowen suggests that sheng is a person who "give passage to" the ways of Heaven - that is, manifests the ways of Heaven through his own person for the benefit of man. Further, it is also noteworthy that the character is composed of the radical or signific er 耳 - the character for ear - and the phonetic cheng 呈 glossed by Karlgren as “to manifest” and by extension “to reveal” or "to disclose." With the role of the signific er - ear -, the character sheng has the sense of "one who hears." That is, the sage hears the ways of Heaven, suggesting his penetration and understanding. We also have to deal with the phonetic of the character cheng, which means to manifest. In this sense, a sage not only hears the ways of Heaven but manifests, reveals, or discloses them to man. Another similar etymology is also possible. According to Jito compiled by Shirakawa Shizuka $(1994,499)$, the word sheng is divided into three elements: er "ear," cheng "to manifest," and kou "mouth." Shirakawa criticizes the view of the Shuowen on the grounds of the phonetic dissimilarity between cheng and sheng. According to him, mouth used here symbolizes a vessel or place in which prayers to gods or Heaven are kept. In any case, these features of sheng reveal that a sage is a wise man who can have contact with Heaven.

21 A clear study of the history of the term sheng is given in $\mathrm{Gu}(1979,80)$. 
the royal order issued in $31 \mathrm{CE}$ in which the Emperor Guangwu 光武 prohibited the minister's usage of sheng toward the emperor (Yoshikawa Tadao 1990).

Sage as the inventor of Chinese civilization - Sheng had yet another meaning in Confucian classics: it was used to signify one who establishes Chinese civilization - in other words, "the inventor of civilization." Such a usage is found in the Book of Rites (Liji 禮記), especially in its chapter "Record of Music" (Yueji 樂記). There is a famous passage which says "one who makes [civilization] is called sheng 'the sage,' and one who correctly expresses it is called ming 明 'the intelligent."” Here, the expression "one who makes [civilization]" means sages of antiquity who established various social systems and their own culture and arts. In this way Confucians employed the special terms "the sage as the monarch of the world" and "the sage as the inventor of civilization."

On the other hand, in the Laozi 老子, one of the most fundamental books of the Daoist tradition, we can find two different meanings of sheng. One is the normal usage of shengren ("sage") in the good, positive sense just as used in Confucianism, signifying an ideal human being (Chapter 2). The other usage of sheng as "sainthood" or "intelligence" is unique to Daoism. Laozi rejects the notion of sheng in the sense of Confucian intelligence and says, "Give up sageness, renounce wisdom, and it will be a hundred times better for everyone" (Chapter 19). Here it is evident that the notion of sheng ("sage") is employed in a negative sense.

Next, in the Zhuangzi 莊子, another fundamental text of Daoism, the key terms which signify an ideal being are zhenren 真人 ("a true person"), shenren 神人 (“a divine person”), and xianren 仙人 (“a transcendent” or “an immortal”). The word zhenren is unique. It is remarkable that the Chinese word zhen itself is never employed in Confucian classics, while it is used in the Zhuangzi many times. $^{22}$ This reveals that zhenren is a fundamentally Daoist notion which should be clearly distinguished from the Confucian sense of sheng ("sage").

On this line of development, an interesting expression was established later by Ge Hong 葛洪 (283-343 or 284-363) of the Jin dynasty: shengren as the one who has attained the Way. Ge Hong was well-known as the author of the Shenxian zhuan 神仙傳 (“Biographies of Divine Transcendents") and the Baopuzi 抱朴子 (“the Master Who Embraces Simplicity”). In a section of the latter work, Ge Hong made a clear contrast between the "sage as the one who has attained

22 The significance of the fact that "zhen" is never used in Confucian classics was first noticed by the seventeenth-century Chinese scholar Gu Yanwu 顧炎武 (1613-1682) in his Rizhi lu 日知 録 “Record of Daily Knowledge.” See Yoshikawa Tadao (1990, 178). 
the Way" and "the sage as the monarch." The latter is obviously a Confucian concept. He states as follows:

Those who are called sages (shengren) by people in this world are the sages as monarchs (zhishi zhi shengren治世之聖人), and not the sages who have attained the Way (dedao zhi shengren 得道之聖人). The sages who attained the Way are represented by the Yellow Emperor and Laozi. The sages as monarchs, on the other hand, are represented by the Duke of Zhou and Confucius.

This view became the standard for the distinction between Confucian and Daoist ideas: Confucians honored those who established the past and the present societies along with the lineage of monarchs, whereas Daoists praised people who had realized truth and "attained the Way." Furthermore, as I explained above, Confucians enumerated only eight sages, which implies that after Confucius no sage had yet appeared again in the world, whereas Ge Hong in his Biographies of Divine Transcendents states as follows:

In ancient times, there were a large number of those who became immortals, and one cannot exhaustively discuss them, but since the rise of the Han dynasty, the number of those who became immortal is forty-five, or, including me, (forty-)six.

Here we confirm that the numbers of "sages" and its Daoist equivalent "transcendents" are quite different. The Confucian tradition does not admit the simultaneous existence of two sages, but Daoists possibly do.

Now let's examine the meaning of sheng in Buddhism. When Buddhism came to China around the beginning of the first century or even earlier, CBT started to employ sheng as a translation of Skt. ārya, by extending the notion to a broader sense. ${ }^{23}$ Skt. arrya is often translated as "noble one" in English. ${ }^{24}$ We have to understand that Ch. sheng is not a literal translation of Skt. ārya "noble one"; the former is merely a Chinese equivalent of the latter in a new cultural context.

It is possible to translate sheng into English "sage" in the case of Buddhism, too. However, I don't think that the word "sage” is entirely sufficient as a translation of sheng in the Buddhist context. The English word "sage" means

23 It is not yet clear at this juncture, however, which translator first began to use sheng as a definitive translation of ārya. According to Enomoto (2009, 352), An Shigao's translation for arryasatya (which is normally translated as shengdi 聖諦 lit. “noble-truth”) was zhendi 眞諦and xianzhedi 賢者諦 in his translation entitled Sidi jing 四諦經; and likewise according to Karashima (2010, 531), another Han translator Lokakșema also uses xianzhe 賢者 for ārya and does not use sheng in his translation Daoxing jing.

24 For the notion of ārya as well as its English translation(s), see Harvey (2009). For the same notion and its Chinese and Tibetan translations, see Enomoto (2009). 
a wise person, which goes perfectly well with the original meaning of sheng in Confucianism. However sheng/ärya in Buddhist texts means not only an intellectual person but also a person who has attained lofty states of mind such as enlightenment as a result of religious practice. This aspect of sheng/ārya in Buddhist texts can be best expressed by "holy one" or "a saint" in my view.

Buddhism generally assumes a distinction between Skt. prthagjana (or Ch. fanfu 凡夫 “the ordinary being”) and ārya (or sheng). The latter, ārya, signifies a human or divine being who excels in virtue and religious experience. In the case of Śrāvaka Buddhism (Voice-hearers Buddhism, or "mainstream" Buddhism), arya/sheng refers to a "stream-enterer," "once-returner," "nonreturner" or "arhat." In Mahayana, ārya/sheng usually means a bodhisattva of the first stage (Skt. prathamā bhūmih, Ch. chudi 初地) or higher. ${ }^{25}$ When such theories of practice and religious attainments are taken into consideration, the English expression "noble one" does not perfectly match the Buddhist meaning. Rather, the religious sense of ärya in Buddhism is much closer to words such as "holy," "holy one" or "saint" in Western terminology. The use of "saint" in the Indian and Tibetan Buddhist contexts are found in studies such as Obermiller (1932, e.g., 130-1, 140-2) and Ray (1994). ${ }^{26}$

Another reason for my preference of "holy one/saint" for Ch. sheng is the Buddhist usage of the term and its relationship with later Christian usages in China. It goes without saying that sheng means "holy" or "sacred" in modern Chinese, especially in the case of Christian terms. When we trace it back to earlier period, we notice that Mattero Ricci uses shengshen 聖神 for saints such as Francis of Assisi in the Tianzhu shiyi 天主實義. ${ }^{27}$ Further, when we shift our viewpoint back to Nestorian Christianity in the Tang dynasty, scholars have noticed the following two points: First, Nestorian texts contain many loan words from Chinese Buddhism such as shizun 世尊, dashi 大師, and dasheng 大聖. And second, modern scholars use the translations "saint" and "holy" for the Nestorian usage of sheng. For example, Tang $(2009,119)$ translates zhisheng 至聖 as “the Holiest." Moreover, noting that qingjing 清淨 and sheng are two terms to signify "holy" in Nestorian texts in the Tang dynasty, the same author (Tang 2009, 126) states as follows:

25 For the definition and the position of a arya/sheng in the system of Buddhist practice, see Funayama (2005, 377-9).

26 However, I don't agree with Ray's assumption that "saints" can be used for any bodhisattvas in Mahayana and for only "arhat" (and not for "stream-enterer," “once-returner," and "non-returner”) in Śrāvaka Buddhism. See Funayama (2005, 406, n. 9).

27 For shengshen, see Shibata (2004, 227, n. 64); see also Shibata (2004, 306, n. 2) for another usage of sheng (shengdian 聖殿) in the Tianzhushiyi. 
The word "Holy" is translated as "Qing Jing” 清淨 in the Luoyang Inscription. It means "peaceful, still, quiet and undisturbed." We also find that in both the "Nestorian Inscription of Xi'anfu" and the Dunhuang manuscript "Zunjing," the word for the Holy Spirit is "Jing Feng 淨風,” the pure wind. (...) The word “sheng 聖” is another option to render the word "holy.” For instance, in the same Zunjing text, the Messiah is called "sheng zi 聖子” (Holy Son). "Sheng” is widely used in modern Chinese for "holy." [Note : omission (...) by FT.]

Moreover, in the case of one of the most important Nestorian texts, entitled A Hymn of the Brilliant Teaching to the Three Majesties for Obtaining Salvation (Jingjiao sanwei mengdu zan 景教三威蒙度讚), which is the Chinese version of the Gloria in Excelsis Deo (Tang 2009, 126), the second and the third paragraphs run as follows (Lin 2003, 125 = Lin 2011, 226-227):

一切善衆至誠礼、一切慧性稱讚歌、一切含真盡歸仰、蒙聖慈光救離魔。 難尋無及正真常、慈父明子淨風王、於諸帝中為師帝、於諸世尊為法皇。

Here we notice the terms sheng 聖 in the second paragraph and shizun 世尊 and fahuang 法皇 in the third. A. C. Moule's English translation of these passages goes as follows:

All the congregation of the good worship with complete sincerity;

All enlightened natures praise and sing;

All who have souls trust and look up to the utmost;

Receiving holy merciful light to save from the devil.

Hard to find, impossible to reach, upright, true, eternal,

Merciful Father, shining Son, holy Spirit, King,

Among all rulers you are Master Ruler,

Among all the world-honoured you are spiritual Monarch.

(Moule 1930, 53. Emphasis by FT)

Regarding the text in question, Chen $(2006,100 ; 2009,203-4)$ points out that the above-stated usage of sheng is certainly based on Buddhist terminology. Further, Forte (1996, 386 and 388) also applies the word "saint" to sheng in both Nestorian and Buddhist texts in the Tang.

I think that the above-mentioned wordings in Nestorian texts and studies thereon undoubtedly reveal that the word sheng should be translated as "a saint" or "holy one" in the Nestorian context, and that such a usage of the word is based on contemporary Buddhist terminology in the Tang. Here I want to emphasize the fact that sheng does not mean "holy one" or "saint" in the Confucian context, but it does in the Nestorian and later Christian contexts. It is hard to explain the usage of sheng in Chinese Christianity directly from the orthodox Confucian idea of the term. It is the notion of sheng in Buddhism that fills in the gap between Confucianism and Christianity. In other words, Buddhist usage of sheng 
has double aspects: sheng as sage (basic sense) and sheng as saint (new sense), and the latter aspect made it possible to use the term in the Christian context too.

\subsection{Conclusions}

In this paper, in order to understand some essential features of CBT, I explored the technique of "translation by matching cultural categories" as a special type of translation which is neither transcription nor translation (translation by meaning) in the strict sense, and I briefly examined some fundamental religious terms such as wuwei-nirvāṇa, dao-bodhi, jing-sūtra, long-nāga, and ganlu-amṛta. Finally, I examined in detail the notion of sheng as well as its Sanskrit counterpart ārya. This type of translation had two consequences: It made it possible for medieval Chinese people to more easily understand difficult notions of Indian Buddhism, but it also posed the danger of misunderstanding the original notion. I would like to claim that some, if not all, of the most fundamental ideas in the religion of the source language could only be translated by using equivalent expressions in the target language. Otherwise it remains untranslatable in the form of transcription. Some early translations, such as An Shigao's use of wuwei for nirvāna, were eventually abolished, and other translators started to use either transcriptions such as niepan or new translations such as miedu.

Finally, if we assume this kind of untranslatability without having recourse to "translation by matching cultural categories," we can take another step to show that the same phenomenon is true of modern translations. I mean that roughly the same paraphrasing process actually takes place in English translation. For example, we cannot translate a Buddhist text without using Christian or Greco-Roman words such as "scripture" for sūtra/jing, "temple" or "monastery” for vihāra/si 寺, “nectar” or "ambrosia” for amrta/ganlu, “monk” for bhikșu/daoshi 道士 or seng 僧, and so on. In this sense, what I call "translation by matching cultural categories" is alive and well today. To understand the history of Chinese Buddhist translations is indeed a task of historical research, but at the same time it provides us an excellent opportunity to reconsider what translation is from a fundamental perspective.

\section{References}

Chen, Huaiyu. 2006. "The Connection between Jingjiao and Buddhist Texts in Late Tang China." In Jingjiao: The Church of the East in China and Central Asia, edited by Roman Malek, 93-113. Sankt Augustin: Institut Monumenta Serica. 
Chen, Huaiyu. 2009. "The Encounter of Nestorian Christianity with Tantric Buddhism in Medieval China." In Hidden Treasures and Intercultural Encounters: Studies on East Syriac Christianity in China and Central Asia, edited by Dietmar W. Winkler and Li Tang, 195-213. Wien: LIT Verlag.

Enomoto, Fumio 榎本文雄. 2009. “'Shishotai' no gen'i to Indo bukkyo ni okeru 'sei'「四聖 諦」の原意とインド仏教における「聖」.” Indo tetsugaku bukkyogakuインド哲学仏教 学 24:354-336.

Forte, Antonino. 1996. "On the So-called Abraham from Persia: A Case of Mistaken Identity." In Paul Pelliot, L'inscription nestorienne de Si-ngan-fou, edited with Supplements by Antonino Forte, 375-418. Kyoto: Scuola di Studi sull'Asia Orientale; Paris: Collège de France, Institut des Hautes Études Chinoises.

Funayama, Toru 船山徹. 2005. "Seija kan no ni keito: Rikucho Zui To bukkyoshi chokan no ichi shiron 聖者觀の二系統——六朝隋唐佛教史鳥瞰の一試論.” In Sankyo kosho ronso 三教 交涉論叢, edited by Mugitani Kunio 麥谷邦夫, 373-408. Kyoto: Kyoto daigaku, Jinbun kagaku kenkyūsho.

Funayama, Toru 船山徹. 2013. Butten wa dou kan'yaku sareta no ka: Sūtora ga kyōten ni naru toki 仏典はどう漢訳されたのか一ースートラが経典になるとき. Tokyo: Iwanami shoten.

Gu, Jiegang 顧頡剛. 1979. “'Sheng' ‘Xian’ guannian he ziyi de yanbian “聖” ‘賢”觀念和字義的 演變.” In Zhongguo zhexue, di yi ji 中國哲學, 第一輯, 80-96. Beijing: Sanlian shudian.

Harvey, Peter. 2009. "The Four Ariya-saccas as 'True Realities for the Spiritually Ennobled' the Painful, its Origin, its Cessation, and the Way Going to This - Rather than 'Noble Truths' Concerning These.” Buddhist Studies Review 26.2:197-227.

Kaginushi, Ryōkei 鍵主良敬. 1968. “Honmu oyobi nyo, shinnyo no yakushutsu ni tsuite 本無 よび如 真如の訳出について.” Ōtani gakuhō大谷學報 47-4: 34-57.

Karashima, Seishi 辛嶋静志. 2010. A glossary of Lokakṣema's translation of the Aștasāhasrikā Prajñāpāramitā. Daoxing bore jing cidian/Dogyo hannya kyo shiten 道行般若經詞典. Tokyo: International Research Institute for Advanced Buddhology, Soka University.

Kieschnick, John. 2003. The Impact of Buddhism on Chinese Material Culture. Princeton: Princeton University Press.

Kobayashi, Masayoshi 小林正美. 1997. “'Kakugi bukkyo’ ko「格義仏教」考.”In Shirīzu Higashi-Ajia bukkyo dai san kan, shin bukkyo no koryū シリーズ 東アジア仏教第3巻新 仏教の興隆, edited by Takasaki Jikido and Kimura Kiyotaka, 293-303. Tokyo: Shunjūsha.

Lin, Wushu 林悟殊. 2003. Tangdai jingjiao zai yanjiu 唐代景教再研究. Beijing: Zhongguo shehui kexue chubanshe.

Lin, Wushu 林悟殊. 2011. Lin Wushu Dunhuang wenshu yu yijiao yanjiu 林悟殊敦煌文書與夷教 研究. Shanghai: Shanghai guji chubanshe.

Mair, Victor H. 2010. “What is Geyi, After All?” In Philosophy and Religion in Early Medieval China, edited by Alan K. Chan and Yuet-Keung Lo, 227-264. Albany: SUNY Press.

Mayeda, Egaku 前田惠學. 1964. Genshi bukkyo seiten no seiritsu shi teki kenkyū 原始佛教聖典 の成立史的研究. Tokyo: Sankibo busshorin.

Mayrhofer, Manfred. 1963. Kurzgefaßtes etymologisches Wörterbuch des Altindischen. A Concise Etymological Sanskrit Dictionary. Band II: D-M. Heidelberg: Carl Winter, Universitätsverlag.

Moule, A. C. 1930. Christians in China before the Year 1550. London: Society for Promoting Christian Knowledge.

Obermiller, E., tr. 1932. History of Buddhism (Chos-hbyung) by Bu-ston. II. Part. The History of Buddhism in India and Tibet. Heidelberg: Harrassowitz. 
Ray, Reginald A. 1994. Buddhist Saints in India: A Study in Buddhist Values \& Orientations. New York/Oxford: Oxford University Press.

Saeki, P. Y. 1937. The Nestorian Documents and Relics in China. Tokyo: The Maruzen Company Ltd.

Shibata, Atsushi 柴田篤. 2004. Tenshu jitsugi 天主実義. Tokyo: Heibonsha.

Shirakawa, Shizuka 白川静. 1994. Jito fukyūban 字統 普及版. Tokyo: Heibonsha.

Tang, Li. 2009. “A Preliminary Study on the Jingjiao Inscription of Luoyang: Text Analysis, Commentary and English Translation." In Hidden Treasures and Intercultural Encounters: Studies on East Syriac Christianity in China and Central Asia, edited by Dieter W. Winkler and Li Tang, 109-132. Wien: LIT Verlag.

Taylor, Rodney L. 1988. "The Sage as Saint: The Confucian Tradition." In Sainthood: Its Manifestations in World Religions, edited by Richard Kieckhefer and George D. Bond, 218-242. University of California Press: Berkeley, Los Angeles and London.

Wogihara. [1979] 1986. Kan'yaku taisho Bonwa daijiten, shinso ban 漢訳対照梵和大辞典 新装版, edited by Suzuki gakujutsu zaidan 鈴木学術財団. Tokyo: Kodansha.

Yoshikawa, Kojiro 吉川幸次郎. [1958] 1968. “Bussetsu Muryojukyo no bunsho 仏説無量寿経 の文章.” In Yoshikawa Kōjirō zenshū dai shichi kan 吉川幸次郎全集第七巻, 510-517. Tokyo: Chikuma shobo.

Yoshikawa Tadao 吉川忠夫. 1990. “Shinjin to seijin 真人と聖人.” In Iwanami koza toyo shiso dai jūyon kan, Chūgoku shuūkyo shiso ni 岩波講座＼cjkstart東洋思想第十四巻、中国宗教思想2, 178-187. Tokyo: Iwanami shoten.

Zacchetti, Stefano. 2002. "An Early Chinese Translation Corresponding to Chapter 6 of the Pețakopadesa. An Shigao's Yinchi ru jing T603 and Its Indian Original: A Preliminary Survey." Bulletin of the School of African and Oriental Studies 65,1: 74-98. 